\title{
Effects of sediment type and food abundance on the vertical distribution of the starfish Asterina pectinifera
}

\author{
Takeo Kurihara*
}

Ishigaki Tropical Station, Seikai National Fisheries Research Institute, Ishigaki Island, Okinawa 907-0451, Japan

\begin{abstract}
The present study investigated how the vertical distribution of the subtidal starfish Asterina pectinifera (Müller \& Troschel) is affected by sediment type and food abundance. During seasonal surveys over 1 yr in Maizuru Bay, Japan Sea, A. pectinifera were abundant in shallow zones ( 3 to $5 \mathrm{~m}$ depth) which were dominated by coarse-grained sediments such as pebbles and oyster shells, while $A$. pectinifera were scarce in deep zones ( 7 to $11 \mathrm{~m}$ depth) which were dominated by fine-grained muddy sediments. Correspondingly, attractiveness of the coarse sediments to A. pectinifera was suggested by the following 3 results. First, for each depth. A. pectinifera occurred more frequently on the coarse sediments than on the fine sediments. Second, marked $A$. pectinifera translocated into the deep zones returned to the shallow zones, while those released into the shallow zones remained. Third, $A$. pectinifera translocated with the coarse sediments into the deep zones remained, while those translocated without the coarse sediments rapidly dispersed. Such attractiveness of the coarse sediments appeared to arise from not microhabitat but food in these sediments, because $A$. pectinifera, translocated with manipulative coarse sediments into the deep zones, did not differ in number between the sediments with or without microhabitats, but preferred sediments with food retained to those with food removed. In conclusion, the vertical distribution of $A$. pectinifera is affected by that of the coarse sediments, because the coarse sediments provide abundant food.
\end{abstract}

KEY WORDS: Subtidal starfish - Vertical distribution - Sediment - Food - Microhabitat

\section{INTRODUCTION}

Factors limiting vertical distributions of organisms have been well studied on intertidal rocky shores by field experiments (Underwood \& Denley 1984). These studies deal with various taxa such as algae (Lubchenco 1980), barnacles (Connell 1961a,b, Denley \& Underwood 1979, Raimondi 1991), limpets (Creese 1980, Branch 1981), gastropods (Underwood \& Barrett 1990), mussels (Paine 1974, Iwasaki 1995a), polychaetes and bryozoans (Keough \& Downes 1982). The main factors specified are depth-dependent changes in the abundance and mortality of juveniles (Denley \& Underwood 1979, Keough \& Downes 1982, Raimondi 1991), competition with other species (Lubchenco 1980), predation (Connell 1961a), desiccation (Iwasaki 1995a) and wave action (Connell 1961b).

·E-mail: takeo@snf-its.affrc.go.jp
Compared with the intertidal zone, few experimental studies on the vertical distributions of organisms have been conducted in the subtidal zone. One feature of the subtidal zone, especially nearshore, is that sediment often shows remarkable vertical changes in terms of grain size or composition. This may influence the vertical distributions of organisms, as sediment frequently affects the distribution patterns of organisms (Snelgrove \& Butman 1994).

The first aim of the present study was to investigate experimentally whether the vertical change in sediment type decreases the density of the subtidal starfish Asterina pectinifera (Müller \& Troschel) with depth. The density of $A$. pectinifera seems to decrease from near the low water level to greater depths, where the sediment type changes from shells and boulders to sand and mud (Kurihara \& Yano in press). This change in sediment type causes the vertical change in $A$. pectinifera density; Levin et al. (1987) suggested from their field observations that sediment type may 
strongly influence the density of $A$. pectinifera. However, this effect of sediment type has not been experimentally demonstrated.

The second aim of the present study was to investigate experimentally how food and microhabitat on sediment alter the density of Asterina pectinifera. The food of A. pectinifera, consisting of algae, sea grass, small sessile macrobenthos and detritus (Bak 1981), seems to be more abundant on coarser sediments (Kurihara unpubl.). This seems also true for microhabitats such as crevices and interstices, where $A$. pectinifera hide presumably to avoid predators, competitors, or high temperature associated with sunlight, as has been suggested for other Asterina species (Crump \& Emson 1983)

\section{MATERIALS AND METHODS}

Study site. Field observations and experiments were conducted using SCUBA at 1 to $11 \mathrm{~m}$ depths near the Kyoto University Fisheries Research Station (35 $29.2^{\prime} \mathrm{N}$, $135^{\circ} 22.3^{\prime}$ E), Maizuru Bay, Japan Sea (Fig. 1). Near the east side of this research station, in a preliminary survey, Asterina pectinifera occurred at a high density in association with abundant pebbles and shells. In this area, stations were set at $1,3,5,7$ and $9 \mathrm{~m}$ depths on 5 transects ( $A$ to $E_{i}$ each 50 to $100 \mathrm{~m}$ long) and additionally at $11 \mathrm{~m}$ depth on 3 transects ( $A$ to $C$ ).

Surface water temperature ranges from $8.0^{\circ} \mathrm{C}$ in winter to $27.8^{\circ} \mathrm{C}$ in summer (Ueno \& Satoh 1994), differing between 1 and $11 \mathrm{~m}$ depth by $<2.3^{\circ} \mathrm{C}$ throughout the year (Tamura 1992). Because Maizuru Bay is a semienclosed embayment, wave-action is weak, except when westerly winds occur in winter or passing boats create wakes. Tides are semidiurnal with a range of $17 \mathrm{~cm}$ from mean low water (MLW) to mean high water (MHW) (Maizuru Marine Observatory 1993, 1994).

To examine potential predator and competitor pressure on Asterina pectinifera, gastropods and starfishes as found in other studies (Mauzey et al. 1968, Branch \& Branch 1980, Stevenson 1992, Okutani 1994) were sur-

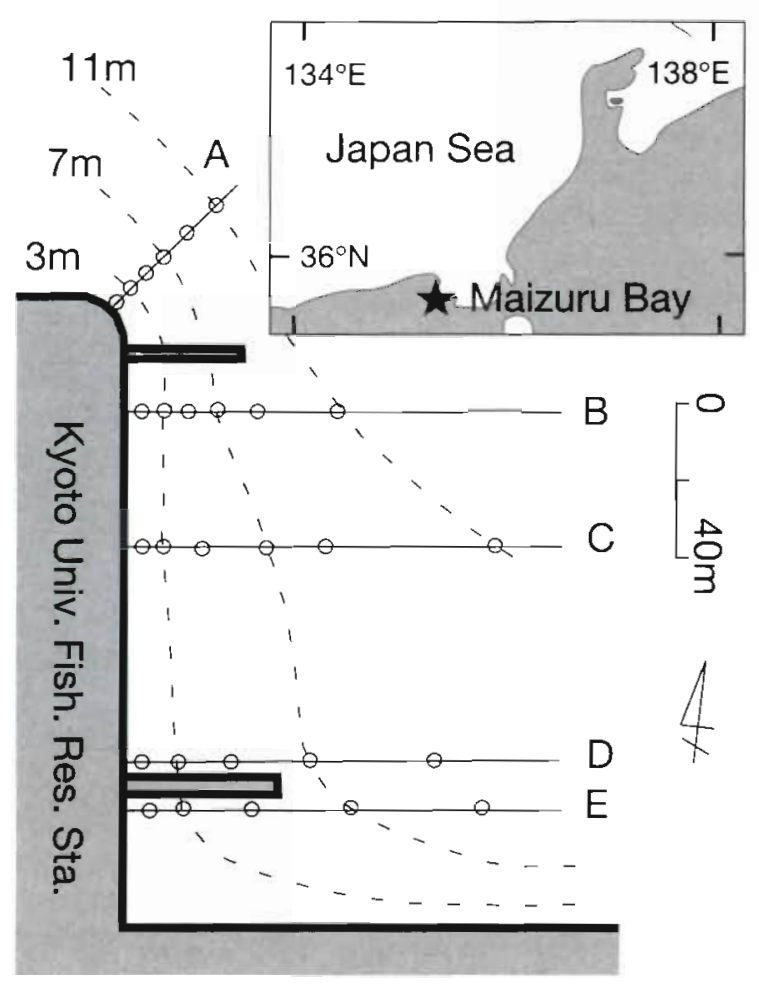

Fig. 1. Maps of the study site. (0) Stations on Transects A to E perpendicular to the shoreline. There is a pontoon between Transects $\mathrm{A}$ and $\mathrm{B}$, and between $\mathrm{D}$ and $\mathrm{E}$

veyed. A possible predator (starfish Luidia quinaria) and possible competitors for food (starfish: Asterina batheri and Astropecten polyacanthus; gastropods: Lunella coronata coreensis and Omphalius sp.) were seasonally observed from summer 1995 to spring 1996 at the above-mentioned stations using 4 to 12 quadrats of $0.25 \mathrm{~m}^{2}$ to estimate their densities. Mean density for each season and transect (Table 1) was highest at $1 \mathrm{~m}$ depth for Omphalius sp. and L. Coreensis, at 3 or $5 \mathrm{~m}$ depth for $A$. batheri and $A$. polyacanthus, and was extremely low at each depth for $L$. quinaria.

Observations on sediment. Sediment type at each station was visually divided into fine-grained sedi-

Table 1. Annual mean density $\left( \pm \mathrm{SE}, \mathrm{m}^{-2}\right.$ ) of a possible predator (Luidia quinaria) and competitors (Omphalius sp., Lunella coronata coreensis, Asterina batheri, and Astropecten polyacanthus) on Asterina pectinifera, presented with the number of individuals $(\mathrm{N})$

\begin{tabular}{|c|c|c|c|c|c|c|c|}
\hline & \multicolumn{6}{|c|}{ Depth (m) } & \multirow[t]{2}{*}{$\mathrm{N}$} \\
\hline & 1 & 3 & 5 & 7 & 9 & 11 & \\
\hline L. quinaria & $0.00 \pm 0.00$ & $0.00 \pm 0.00$ & $0.00 \pm 0.00$ & $0.02 \pm 0.02$ & $0.00 \pm 0.00$ & $0.09 \pm 0.09$ & 2 \\
\hline Omphalius sp. & $12.51 \pm 2.10$ & $1.95 \pm 0.63$ & $0.13 \pm 0.06$ & $0.00 \pm 0.00$ & $0.00 \pm 0.00$ & $0.00 \pm 0.00$ & 954 \\
\hline L. coreensis & $0.17 \pm 0.06$ & $0.00 \pm 0.00$ & $0.00 \pm 0.00$ & $0.00 \pm 0.00$ & $0.00 \pm 0.00$ & $0.00 \pm 0.00$ & 13 \\
\hline A. batheri & $0.03 \pm 0.02$ & $0.11 \pm 0.04$ & $0.06 \pm 0.04$ & $0.00 \pm 0.00$ & $0.00 \pm 0.00$ & $0.00 \pm 0.00$ & 17 \\
\hline A. polyacanthus & $0.00 \pm 0.00$ & $0.02 \pm 0.02$ & $0.22 \pm 0.13$ & $0.18 \pm 0.06$ & $0.11 \pm 0.07$ & $0.09 \pm 0.09$ & 21 \\
\hline
\end{tabular}


ments ('fine sediments') and coarse-grained sediments ('coarse sediments'). More than $60 \%$ of the fine sediments consisted of fine mud $(<63 \mu \mathrm{m}$ diameter $)$ at $<11 \mathrm{~m}$ depths (Saitoh pers. comm.). Coarse sediments consisted of pebbles and bivalve shells. In May 1993, coarse sediments were randomly collected with shovels at 1 to $5 \mathrm{~m}$ depths between Transects $B$ and D to measure the longest axis, and were also observed 3 times for 12 quadrats of $0.25 \mathrm{~m}^{2}$ at each station to estimate the percentage cover to an accuracy of $\pm 10 \%$ (Fig. 2).

Observations on the distribution of Asterina pectinifera. Density of $A$. pectinifera was estimated at all stations to examine whether the vertical distribution of A. pectinifera corresponded to that of coarse sediments. The number of $A$. pectinifera was counted in a $0.25 \mathrm{~m}^{2}$ quadrat thrown 12 times around each station. This survey was conducted twice in summer (June to August 1993), and 3 times in each of winter (December 1993 to February 1994), spring (March to May 1994), and autumn (September to November 1994). Only $A$. pectinifera for which the whole body was visible vertically from above were counted to prevent overestimating the density on complex sediments with abundant microhabitats.

During these surveys, the density of Asterina pectinifera for each sediment type was also estimated at each depth. Separately for coarse sediments and fine sediments, the number of $A$. pectinifera was counted at each station at 3,5 , and $7 \mathrm{~m}$ depths, where both coarse sediments and fine sediments occurred on each transect (Fig. 2). The number of $A$. pectinifera was summed for each station, and divided by the area of each sediment type at the station. A. pectinifera located on the boundary between the 2 sediments or on other sediments (e.g. garbage) were not counted.

Mark-recapture experiments. Marked Asterina pectinifera were released and tracked on coarse sediments at 3 to $5 \mathrm{~m}$ depths and on fine sediments at $>5 \mathrm{~m}$ depths; if $A$. pectinifera prefer coarse sediments, then the starfish released on coarse sediments would move at random, while those released on fine sediments would move toward coarse sediments. For the experiments, 238 individuals of $A$. pectinifera were randomly collected from 1 to $9 \mathrm{~m}$ depths around the study sites, and individually marked by branding some arms with a soldering iron (see Kurihara 1998). In August 1994 at Transect C (Fig. 1), half of the starfish (i.e. 119 individuals) were released on coarse sediments at $5 \mathrm{~m}$ depth and the other half on fine sediments at $7 \mathrm{~m}$ depth. Then, 13 and $44 \mathrm{~d}$ later, these marked $A$. pectinifera were counted in 63 discontiguous $4 \mathrm{~m}^{2}$ plots that were arranged in $7 \times 9$ grids in an area of $30 \times 40 \mathrm{~m}^{2}$ (see Fig. 4). Each of these $4 \mathrm{~m}^{2}$ plots consisted of 16 contiguous $0.25 \mathrm{~m}^{2}$ quadrats in which the percentage

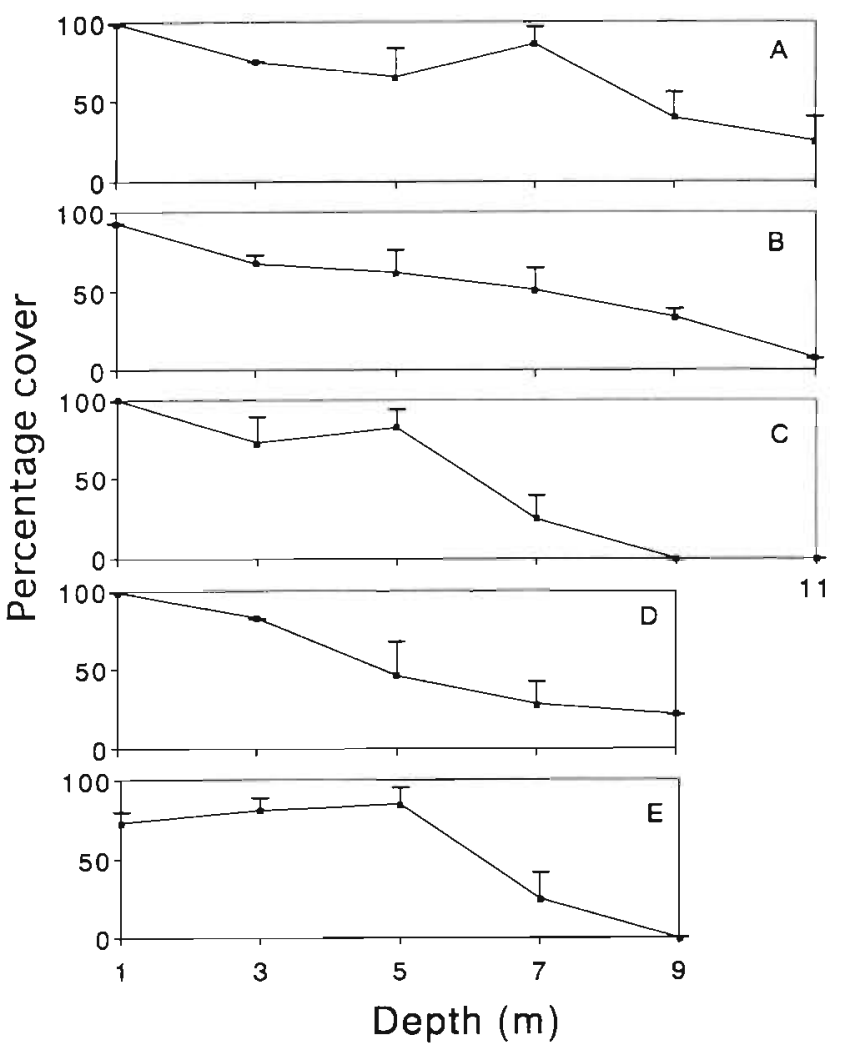

Fig. 2. Mean + SE percentage cover of coarse sediments on Transects A to E during 3 observations in May 1993

cover of coarse sediments was determined in the above-mentioned way. For each $A$. pectinifera found, the identification code and the sediment on which it was located were recorded.

Observations on food and microhabitat. Asterina pectinifera is reported to be an omnivorous feeder (Bak. 1981, Jangoux 1982, Levin et al. 1987). Conformingly, in a preliminary survey at the study site, $A$. pectinifera $(\mathrm{N} \approx 1400$ ) showed stomach-everting feeding behavior on (1) algae, (2) small macrobenthos and (3) detritus. Abundances of these foods were estimated for each sediment type in the following way. (1) The abundance of algae was seasonally estimated from summer 1995 to spring 1996 at $3 \mathrm{~m}$ depth at the 5 transects (Fig. 1). Presence and absence of the dominant algae (Dictyopteris undulata, Eudarachne binghamiae, Hypnea charoides, Sargassum autumnale, Ulva pertusa) were scored as 1 and 0, respectively, for each type of sediment in $0.25 \mathrm{~m}^{2}$ quadrats thrown 4 to 12 times at each station. These scores were averaged for each station and then divided by the areas covered for each sediment type ('abundance index'). The abundance index for an alga and sediment type will increase with an increase in the number of quadrats containing the alga, or with a decrease in the area covered by the sed- 
iments. (2) The density of the dominant small macrobenthos (Polyplacophora: Acanthopleura sp., Gastropoda: Mitrella bicincta, Ascidiacea: Styela plicata) were estimated by counting them for each sediment type in the quadrats during the above-mentioned algal abundance survey. (3) The abundance of detritus was estimated from the frequency of stomach-everting behavior of $A$. pectinifera, assuming that the frequency of stomach-everting behavior would be higher where detritus is abundant. To calculate this frequency for each sediment, stomach-everting behavior of $A$. pectinifera occurring with no discernible food was seasonally observed at 1 to $9 \mathrm{~m}$ depths from autumn 1995 to summer 1996.

To investigate the availability of microhabitats on coarse sediments and fine sediments, hiding behavior of Asterina pectinifera was observed during the abovementioned survey for starfish distribution. A. pectinifera, which hid in the sediments and thus were not visible from above, were counted by turning over coarse sediments and digging in fine sediments.

Translocation experiments. To investigate whether food and/or microhabitat in coarse sediments attract $A$. pectinifera, starfish were translocated with or without manipulated coarse sediments to the deeper area covered by fine sediments. For the experiments, 20 discontiguous $1 \mathrm{~m}^{2}$ plots were arranged $5 \mathrm{~m}$ apart on the seabed at $\sim 7 \mathrm{~m}$ depth between Transects $A$ and D (Fig. 1). These plots were divided into 5 clusters in each of which 4 treatments (FM, FX, XM and XX) were arranged. On 17 March 1997, coarse sediments were translocated to FM with no manipulation (i.e. with Food and Microhabitat retained), and to FX after being broken into pieces of 3 to $4 \mathrm{~cm}^{2}$ (i.e. with Food retained and microhabitat eXcluded), and to XM after being dried in the sun and washed, resulting in no organisms on the sediments except for polychaete tubes and barnacle shells (i.e. with food excluded and Microhabitat retained). No coarse sediment was translocated into $\mathrm{XX}$ (i.e. with food and microhabitat eXcluded). In each plot, 5 A. pectinifera randomly collected at 3 to $5 \mathrm{~m}$ depths were released with individual marks on $18 \mathrm{March} 1997$. resulting in a density $\left(5.0 \mathrm{~m}^{-2}\right)$ similar to that at $3 \mathrm{~m}$ depth $\left(4.7 \mathrm{~m}^{-2}\right.$ in a preliminary survey). Then, $1,2,3,4$, and $9 \mathrm{~d}$ later, the number of marked $A$. pectinifera were recorded with their stomach-everting and hiding behaviors, although 1 of the 5 replicate clusters failed to be observed on Days 3 and 4 due to problems with SCUBA. The number of $A$. pectinifera was compared in 3 ways: between FM and XX, to compare attractiveness between coarse and fine sediments; between FM and FX or between XM and XX, to test for attractiveness to microhabitat in coarse sediment; and, between FM and $\mathrm{XM}$ or between FX and XX, to test for attractiveness to food on coarse sediments.
Statistical analysis. In the mark-recapture experiments, the direction of starfish movement was tested for randomness, using a Rayleigh test (Zar 1996). To do this test for each of Days 13 and $44,-5$ and $-15 \%$ of the found starfish with less clear marks were excluded, respectively, considering the misidentification rate in a laboratory experiment (Kurihara 1998). Additionally, 4 Asterina pectinifera that were found on both days were excluded from the analysis of Day 13, to avoid excessive Type I or II error from repeated measures (Underwood 1997).

In the translocation experiments, the number of starfish was compared by a 3-way orthogonal ANOVA. without replication (treatments of food and microhabitat: fixed factors, Day: a random factor). For each treatment, a different plot of the 5 replicate plots was assigned to each of the 5 days to avoid repeated measures of the same plot. Data were $\log _{10}(n+1)$-transformed, as they included zeros (Zar 1996)

The abundance of starfish or food could not be statistically compared between sediment types or depths, because it differed in both variances and sample sizes between treatments, thus violating assumptions for statistical testing (Underwood 1997).

\section{RESULTS}

\section{Distribution pattern of Asterina pectinifera}

At 3 and $5 \mathrm{~m}$ depths, Asterina pectinifera were found on 2 to 5 transects for each date. At $7 \mathrm{~m}$ depth, A. pectinifera were found on 0 to 3 transect(s) for each date. At 9 and $11 \mathrm{~m}$ depths, A. pectinifera were found on only 1 survey date on Transects $A$ and $B$, respectively. The distribution pattern is well represented in Fig. 3, where mean density of $A$. pectinifera within each season was higher at 3 and $5 \mathrm{~m}$ depths than at greater depths, except for summer and spring on Transect $A$ and for spring on Transect $D$.

This distribution pattern of Asterina pectinifera corresponds to the vertical change in the percentage cover of coarse sediments (Fig. 2). Coarse sediments, consisting of pebbles (mean $\pm \mathrm{SE}$ length of the longest axis $=42.0 \pm 2.1 \mathrm{~mm} ; \mathrm{N}=76)$ and shells $(60.2 \pm 3.0 \mathrm{~mm}$; $\mathrm{N}=133$ ), showed higher percentage cover at 3 and $5 \mathrm{~m}$ depths than at greater depths, except for Transect $A$. The correspondence between the starfish distribution and percentage cover suggests the aggregation of $A$. pectinifera on coarse sediments. This is reflected by the fact that within each of 60 combinations of transects, seasons and depths starfish density on coarse sediments was generally higher than (32 combinations) or equal to (23 combinations) the density on fine sediments (Table 2). 

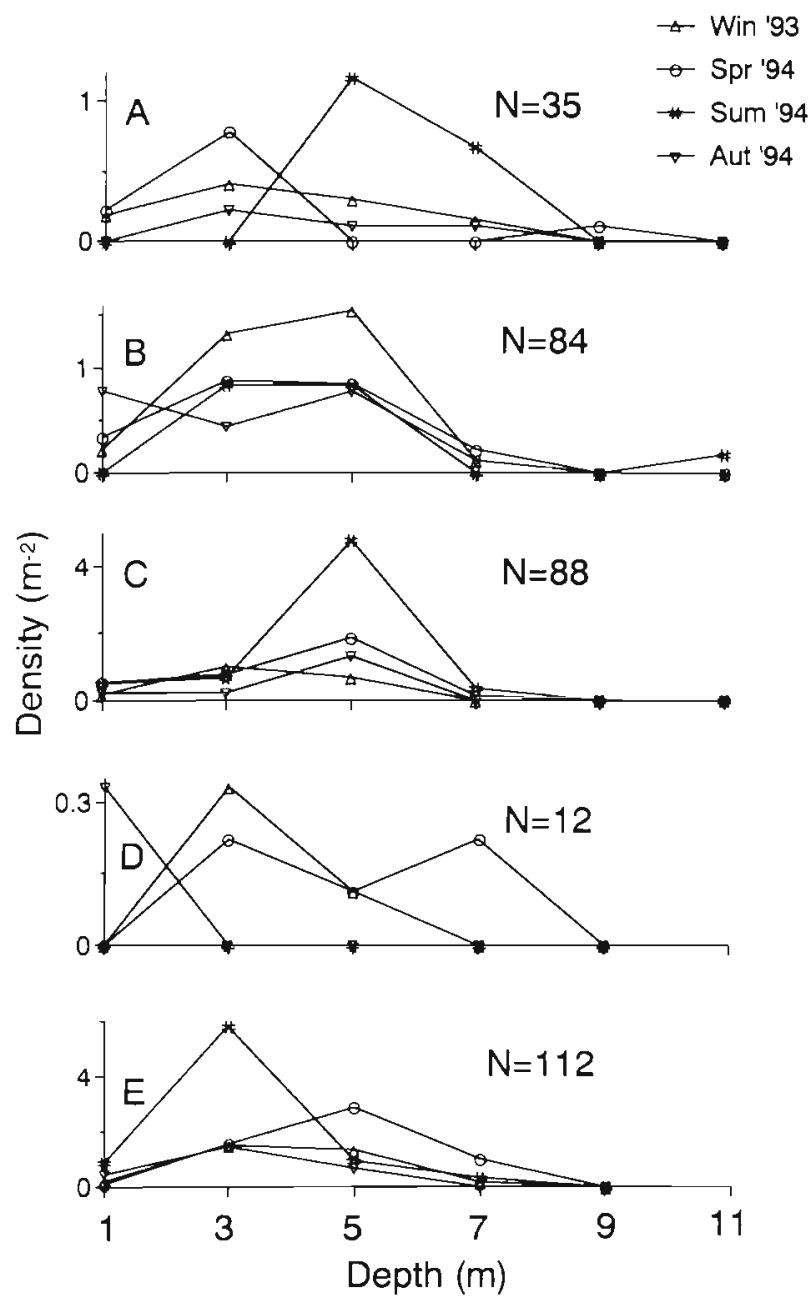

Fig. 3. Asterina pectinifera. Seasonal mean densities $\left(\mathrm{m}^{-2}\right)$ of starfish with the number of individuals $(N)$ for each transect (A to E). Note that the $y$-axis scale differs among transects
In contrast, low starfish densities in autumn, on Transect $D$, and at $1 \mathrm{~m}$ depth did not correspond to any temporal or spatial fluctuations in the percentage cover of coarse sediments (Figs. $2 \& 3$ ). Percentage cover of coarse sediments did not seasonally fluctuate at the study site. The percentage cover on Transect D was similar to that on the other transects. The percentage cover at $1 \mathrm{~m}$ depth was higher than that at the greater depths for most transects. The causes of this low density of Asterina pectinifera will be discussed later.

\section{Movement of marked Asterina pectinifera}

During the mark-recapture experiments, none of the marked Asterina pectinifera were found outside the 30 $\times 40 \mathrm{~m}^{2}$ experimental area. Inside the area, 41 and 14 marked $A$. pectinifera were found on Days 13 and 44 , respectively. Of these, 2 and 4 individuals with unclear brands were excluded. In total, 49 individuals were analyzed (Fig. 4), of which $4 \mathrm{~A}$. pectinifera were found on both days. The decrease in recaptured individuals from Day 13 to Day 44 corresponds to a decrease in mean starfish density from summer to autumn (Fig. 3).

On Day 13 (Fig. 4a), none of the marked Asterina pectinifera released at 5 or $7 \mathrm{~m}$ depth showed significant directional movement $(\mathrm{p}>0.10$ for both in Rayleigh test, excluding $A$. pectinifera found on both days); $A$. pectinifera released at $5 \mathrm{~m}$ depth moved a shorter distance from the release point than $A$. pectinifera at $7 \mathrm{~m}$ depth (mean $\pm \mathrm{SD}$ distance: $1.9 \pm 0.4 \mathrm{~m}$ and $3.7 \pm 1.1 \mathrm{~m}$, respectively). On Day 44 (Fig. $4 \mathrm{~b}$ ), $A$. pectinifera released at $5 \mathrm{~m}$ depth did not show significant directional movement, but $A$. pectinifera released at $7 \mathrm{~m}$ depth did $(\mathrm{p}>0.10$ and $\mathrm{p}<0.005$, respectively).

Table 2. Asterina pectinifera. Mean density $\left(\mathrm{m}^{-2}\right)$ for coarse and fine sediments, with range in parentheses

\begin{tabular}{|c|c|c|c|c|c|c|c|c|c|c|}
\hline \multirow{2}{*}{$\begin{array}{l}\text { Depth } \\
\text { (m) }\end{array}$} & \multicolumn{2}{|c|}{ Transect A } & \multicolumn{2}{|c|}{ Transect B } & \multicolumn{2}{|c|}{ Transect C } & \multicolumn{2}{|c|}{ Transect D } & \multicolumn{2}{|c|}{ Transect $E$} \\
\hline & Coarse & Fine & Coarse & Fine & Coarse & Fine & Coarse & Fine & Coarse & Fine \\
\hline \multicolumn{11}{|c|}{ Winter 1993} \\
\hline 3 & $0.22(0.44)$ & 0.00 & $0.65(1.96)$ & $0.35(1.04)$ & $0.91(1.82)$ & 0.00 & $0.13(0.40)$ & 0.00 & $2.13(4.27)$ & 0.00 \\
\hline 5 & 0.00 & 0.00 & $0.89(2.67)$ & 0.00 & $0.53(1.20)$ & 0.00 & 0.00 & 0.00 & $0.78(1.57)$ & 0.00 \\
\hline 7 & 0.00 & 0.00 & 0.00 & 0.00 & 0.00 & 0.00 & 0.00 & 0.00 & $0.67(1.33)$ & 0.00 \\
\hline \multicolumn{11}{|c|}{ Spring 1994} \\
\hline 3 & $0.59(0.44)$ & 0.00 & $0.49(0.98)$ & $0.35(1.04)$ & $0.76(0.45)$ & $0.42(1.25)$ & 0.00 & 0.00 & $1.24(2.07)$ & 0.00 \\
\hline 5 & 0.00 & 0.00 & $0.89(2.67)$ & 0.00 & $0.67(2.00)$ & $0.67(2.00)$ & 0.00 & 0.00 & $0.52(0.39)$ & 0.00 \\
\hline 7 & 0.00 & 0.00 & $0.22(0.65)$ & 0.00 & 0.00 & 0.00 & $0.40(1.20)$ & 0.00 & $1.78(4.00)$ & $0.33(1.00)$ \\
\hline \multicolumn{11}{|c|}{ Summer 1994} \\
\hline 3 & 0.00 & 0.00 & $0.49(0.00)$ & $1.57(1.04)$ & $0.68(0.45)$ & 0.00 & 0.00 & 0.00 & $6.22(1.66)$ & $0.85(1.70)$ \\
\hline 5 & $1.02(2.04)$ & 0.00 & $1.07(1.07)$ & $0.44(0.89)$ & $5.10(3.00)$ & 0.00 & 0.00 & 0.00 & $1.14(1.49)$ & 0.00 \\
\hline 7 & 0.00 & 0.00 & 0.00 & 0.00 & $0.67(1.33)$ & $0.22(0.44)$ & 0.00 & 0.00 & 0.00 & $0.25(0.50)$ \\
\hline \multicolumn{11}{|c|}{ Autumn 1994} \\
\hline 3 & $0.15(0.44)$ & $0.46(1.37)$ & $0.65(0.98)$ & 0.00 & $0.30(0.91)$ & 0.00 & 0.00 & 0.00 & $1.52(2.07)$ & 0.00 \\
\hline 5 & $0.17(0.51)$ & 0.00 & $1.24(3.73)$ & 0.00 & $1.07(0.80)$ & 0.00 & 0.00 & 0.00 & $0.65(0.78)$ & 0.00 \\
\hline 7 & 0.00 & $0.81(2.44)$ & 0.00 & $0.23(0.68)$ & 0.00 & 0.00 & 0.00 & 0.00 & 0.00 & 0.00 \\
\hline
\end{tabular}


(a) Day 13
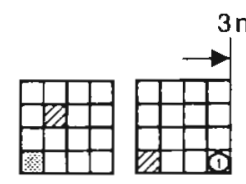

$3 m$
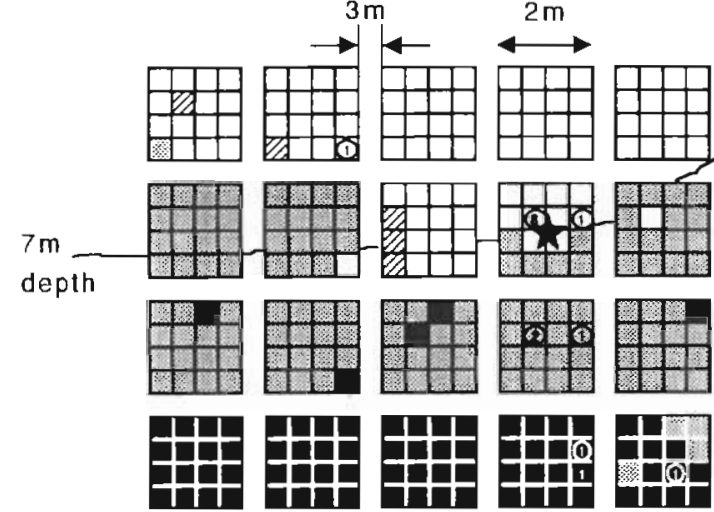

(a)
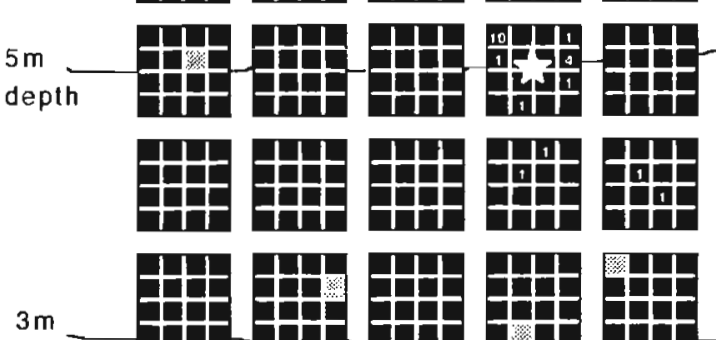

$3 \mathrm{~m}$

depth (b) Day 44

\begin{tabular}{|llll}
\hline $0-20$ & $30-60$ & $60-80$ & $80-100$
\end{tabular}

$\uparrow$ Percentage cover of Coarse Sediments
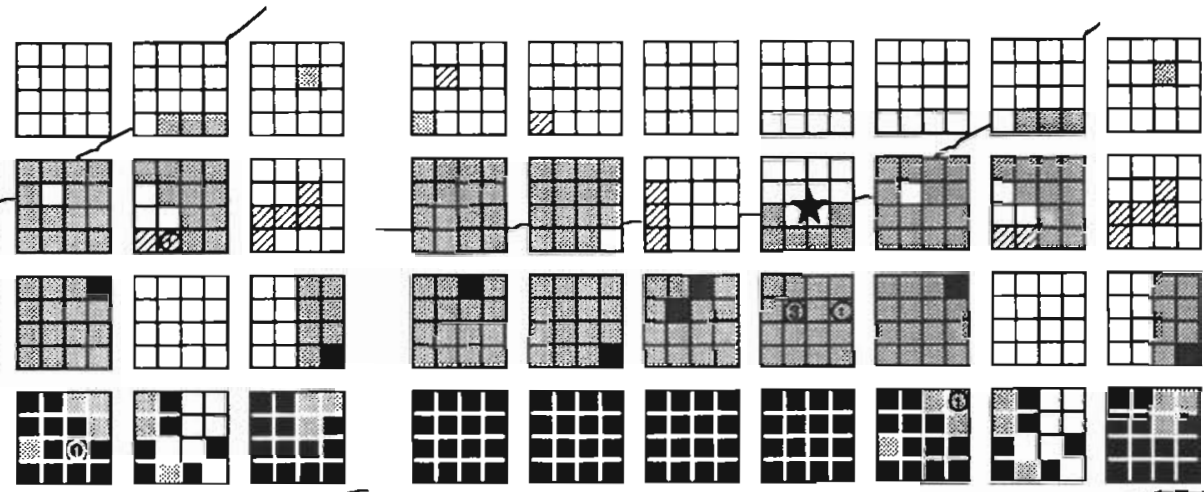

Fi

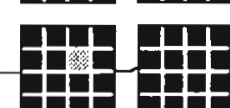
井井
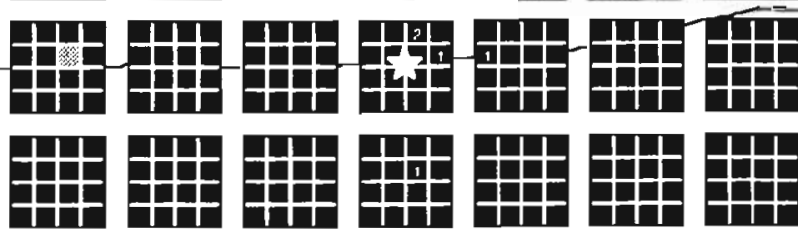



Fig. 4. Asterina pectinifera. Results of the mark-recapture experiments. Arrangement of $0.25 \mathrm{~m}^{2}$ quadrats at $\geq 3 \mathrm{~m}$ depth is shown with positions of marked starfish (a: Day 13, b: Day 44). In each quadrat, percentage cover of coarse sediments is shown at 5 grades. Release points at 7 and $5 \mathrm{~m}$ depths are denoted by ( $\star$ ) and ( $)$. The numbers of recaptured starfish that were released at 7 and $5 \mathrm{~m}$ depth points are denoted by numerals with and without circle, respectively, excluding the starfish with unclear marks. Quadrats at $<3 \mathrm{~m}$ depths are not given here, as the percentage cover of coarse sediments was constantly 80 to $100 \%$ and no marked starfish were found. Note that the scale of the figure differs among objects

Similar to Day 13, A, pectinifera released at $5 \mathrm{~m}$ moved a shorter distance than $A$. pectinifera at $7 \mathrm{~m}$ (mean \pm SD distance: $2.5 \pm 1.0 \mathrm{~m}$ and $6.0 \pm 1.2 \mathrm{~m}$, respectively). During the experiments, all marked $A$. pectinifera were found on a lump of coarse sediments (note that there were some lumps even in the $0.25 \mathrm{~m}^{2}$ quadrats with 0 to $20 \%$ percentage cover of coarse sediments in Fig. 4).

Food abundance and frequency of hiding behavior

The small macrobenthos density, abundance index of algae, and stomach-everting rate, averaged for all transects and seasons (Table 3), were generally higher on coarse sediments than fine sediments. For each transect, season and species, the small macrobenthos density was higher by 0 to $6.9 \mathrm{~m}^{-2}$ on coarse sediments than fine sediments (data not shown). This was also true for algae with an abundance index higher by 0 to 4.8 on coarse sediments, except for Sargassum autumnale on Transect D in winter. For each season, the stomach-everting rate was higher on coarse sediments ( 45.5 to $66.7 \% ; N=6$ to 155$)$ than fine sediments $(0$ to $50 \% ; \mathrm{N}=1$ to 8 )
Hiding behavior was observed for $29.2 \%$ of 414 Asterina pectinifera on coarse sediments, while this behavior was not observed for the $70 \mathrm{~A}$. pectinifera on fine sediments.

Table 3. Indices of food abundance (mean \pm SE) with the number of observed individuals in parentheses. Stomach-everting rate indicates abundance of detritus. For the calculation procedure of each index see 'Materials and methods: Observations on food and microhabitat'

\begin{tabular}{|lcc|}
\hline & $\begin{array}{c}\text { Coarse } \\
\text { sediment }\end{array}$ & $\begin{array}{c}\text { Fine } \\
\text { sediment }\end{array}$ \\
\hline Abundance index of algae & & \\
Dictyopteris undulata & $0.15 \pm 0.13$ & $0.00 \pm 0.00$ \\
Eudarachne binghamiae & $0.41 \pm 0.18$ & $0.00 \pm 0.00$ \\
Hypnea charoides & $0.76 \pm 0.32$ & $0.00 \pm 0.00$ \\
Sargassum autumnale & $0.26 \pm 0.17$ & $0.29 \pm 0.29$ \\
Ulva pertusa & $0.55 \pm 0.25$ & $0.00 \pm 0.00$ \\
Density (m ${ }^{-2}$ ) of small macrobenthos & \\
Acanthopleura sp. & $0.43 \pm 0.32(22)$ & 0.00 \\
Mitrella bicincta & $1.77 \pm 0.66(93)$ & 0.00 \\
Styela plicata & $0.08 \pm 0.05(26)$ & 0.00 \\
Stomach-everting rate (\%) of Asterina pectinifera & \\
& $58.8(250)$ & $26.3(19)$ \\
\hline
\end{tabular}




\section{Emigration of Asterina pectinifera from translocated plots}

In the translocation experiments (Table 4), marked Asterina pectinifera remained in the experimental plots with food (FM and FX), and rapidly dispersed from those without food (XM and XX). The number of A. pectinifera was significantly larger in the plots with food than without food: $\mathrm{p}=0.02, F=\left(\mathrm{SS}_{\mathrm{Food}} / \mathrm{df}_{1}\right) /$ $\left(\mathrm{SS}_{\text {Food }} \times \mathrm{Duy}_{\mathrm{ay}} / \mathrm{df}_{2}\right)=(0.35 / 1) /(0.10 / 4)$. Unexpectedly, the number was slightly larger in the plots without microhabitats than with microhabitats, although not significantly: $\mathrm{p}=0.45, F=\left(\mathrm{SS}_{\text {Microhabitat }} / \mathrm{df}_{1}\right) /\left(\mathrm{SS}_{\text {Microhabitat } \times \text { Day }} /\right.$ $\left.\mathrm{df}_{2}\right)=(0.011 / 1) /(0.064 / 4)$. The number of $A$. pectinifera was not significantly affected by the factor Day or interactions ( $\mathrm{p}>0.05)$. Stomach-everting behavior was found in $50.0 \%$ of $A$. pectinifera for FM ( $\mathrm{N}=22$; Days 1 to 9 pooled) and $79.4 \%$ for $\mathrm{FX}(\mathrm{N}=34)$. Hiding behavior was found only for FM $(31.8 \% ; \mathrm{N}=22)$.

Table 4. Asterina pectinifera. Mean \pm SE number of starfish in the translocation experiments. Starfish number is presented for each plot where coarse sediments were translocated with no manipulation (FM), after removing microhabitats (FX) and after removing food $(X M)$, or not translocated (XX). See Results' for statistical tests

\begin{tabular}{|c|c|c|c|c|}
\hline \multirow[t]{2}{*}{ Day } & \multicolumn{4}{|c|}{ Number of starfish } \\
\hline & FM & $\mathrm{FX}$ & $\mathrm{XM}$ & $\mathrm{XX}$ \\
\hline 1 & $1.6 \pm 0.40$ & $1.6 \pm 0.68$ & 0.0 & 0.0 \\
\hline 2 & $1.4 \pm 0.51$ & $1.8 \pm 0.58$ & 0.0 & 0.0 \\
\hline 3 & $0.75 \pm 0.25$ & $2.0 \pm 0.41$ & 0.0 & 0.0 \\
\hline 4 & $0.50 \pm 0.50$ & $1.5 \pm 0.29$ & 0.0 & 0.0 \\
\hline 9 & $0.40 \pm 0.24$ & $0.60 \pm 0.24$ & 0.0 & 0.0 \\
\hline
\end{tabular}

\section{DISCUSSION}

\section{Effects of coarse sediments on the vertical distribution of Asterina pectinifera}

Asterina pectinifera was more abundant at 3 to $5 \mathrm{~m}$ depths than at greater depths, which was at least partly due to the presence of coarse sediments at 3 to $5 \mathrm{~m}$ depths. This is supported by the following results: correspondence between their vertical distribution patterns at $\geq 3 \mathrm{~m}$ depth (Figs. $2 \& 3$ ); higher density of A. pectinifera on coarse sediments (Table 2); movement of marked $A$. pectinifera toward coarse sediments in the mark-recapture experiments (Fig. 4); lower emigration rate of $A$. pectinifera from coarse sediments than from fine sediments in the translocation experiments (compare FM and XX in Table 4).

Although predators, competitors and water temperature also have been suggested to decrease the density of starfish with increasing depth (Mauzey et al. 1968, Gage et al. 1984, Stevenson 1992), none are considered to vertically change the density of Asterina pectinifera at $\geq 3 \mathrm{~m}$ depth in the present study site. Luidia quinaria, a possible predator of $A$. pectinifera, was found at a low density (Table 1), and appears to eat few A. pectinifera: only one L. quinaria among 103 individuals observed had $A$. pectinifera (or perhaps another starfish) in its stomach, and the other $L$. quinaria mainly had bivalves and/or echinoids (Kurihara pers. obs.). Other predators such as Pleuroploca trapezium (Okutani 1994) and other starfish of the family Luididae (Jangoux 1982) were not found. Although possible competitors such as Omphalius sp., Lunella coronata coreensis, Asterina batheri, and Astropecten polyacanthus were observed at high density (Table 1), they were less abundant at $\geq 7 \mathrm{~m}$ depth than at $\leq 5 \mathrm{~m}$ depth, which does not appear to cause lower density of $A$. pectinifera at $\geq 7 \mathrm{~m}$ depth. The annual mean water temperature at the present study site differs by $<2^{\circ} \mathrm{C}$ between 3 to $5 \mathrm{~m}$ and $10 \mathrm{~m}$ depths (Tamura 1992), which is unlikely to affect the density of A. pectinifera, considering the large spatial variation in water temperature $\left(>10^{\circ} \mathrm{C}\right)$ over the geographical range of $A$. pectinifera (Kurihara 1996).

In contrast with the density change from $3-5 \mathrm{~m}$ to $\geq 7 \mathrm{~m}$ depths, fluctuations among seasons, among transects, and between $1 \mathrm{~m}$ and 3 to $5 \mathrm{~m}$ depths (Fig. 3) appear to be unrelated to sediment type. The low density in autumn is likely to be due to fluctuations in the mortality rate. This is supported by observations that white Asterina pectinifera (i.e. dying specimens) were found at the study site with a higher frequency during autumn $(-30 \%)$ than spring $(\sim 9 \%)$. The cause of the extremely low density on Transect $D$ is not clear. The lower density at $1 \mathrm{~m}$ depth might have been caused by competition for food with gastropods which were abundant there (Table 1). Such exploitative competition for food between starfish and gastropods has been reported by Branch \& Branch (1980). Mechanisms of these density fluctuations among seasons, transects and depths at $<3 \mathrm{~m}$ require further examination.

\section{Role of coarse sediments}

Availability of microhabitats on coarse sediments may not increase density of Asterina pectinifera at $\geq 3 \mathrm{~m}$ depth. This is supported by the translocation experiments (Table 4) in which, unexpectedly, A. pectinifera stayed with slightly greater frequency in the plots without microhabitats than those with microhabitats. Although microhabitats provide some benthic animals with shelters from wave action and predators (e.g. Lubchenco 1980), these appear to be unimportant 
for A. pectinifera at $\geq 3 \mathrm{~m}$ depth at the present study site. This is presumably because at the study site wave action is weak and possible predators are rare (Table 1). The greater number of $A$. pectinifera without microhabitats than with microhabitats is perhaps ascribable to odor emitted by injured sessile organisms on the experimentally broken coarse sediments (see Moore \& Lepper 1997 for attractivity of odor to starfish)

In contrast with microhabitat, abundant food in coarse sediments seems to increase the density of Asterina pectinifera (Table 3). This is supported by the translocation experiments in which marked $A$. pectinifera, frequently showing stomach-everting behavior, stayed only in the experimental plots containing food (Table 4). Food in some specific sediments and the density of some other starfishes are also closely related, as is suggested for Astropecten latespinosus and organic matter in sand (Nojima 1989), and for Atlantic subtidal starfishes and mussels on boulders (Himmelman \& Dutil 1991).

In summary, the density of Asterina pectinifera decreases from $3-5 \mathrm{~m}$ to $\geq 7 \mathrm{~m}$ depths, at least partly because coarse sediments with abundant food decrease in the deeper zone. In the intertidal zone, the effect of sediments on the vertical distribution of benthic organisms has been reported only for a few species (Underwood \& Barrett 1990, Iwasaki 1995b). In the subtidal zone, however, because sediment type often varies among depths, such phenomena can be observed more generally and should be experimentally studied in the future.

Acknowledgements. I am grateful to Drs W. Sakamoto, K Iwasaki, H. Nakahara, M. Ueno, J. St John and to 4 referees for their comments on the manuscript. I thank K. Nakayama, J. Arakawa, Y. Matsuzawa, H. Tanaka, T. Bandoh, S. Harada, T Takahashi, M. Matsui, H. Saitoh-samatachi and the staff of Kyoto University Fisheries Research Station for their assistance with the field experiments. I am indebted to the staff of Seikai National Fisheries Research Institute for giving me advice on this study.

\section{LITERATURE CITED}

Bak HP (1981) Feeding habits of the sea star, Asterna pectinifera (Müller et Troschel) and its grazing effect on the eelgrass, Zostera marina L. Pub] Amakusa Mar Biol Lab Kyushu Univ 6:1-8

Branch GM (1981) The biology of limpets: physical factors, enercyy flow, and ecological interactions. Oceanogr Mar Biol innu Rev 19:235-380

Branch G^1, Branch ML (1980) Competition between Cellana tramoserica (Sowerby) (Gastropoda) and Patiriella exigua (Lamarck) (Asteroidea), and their influence on algal standing stocks. J Exp Mar Biol Ecol 48:35-49

Connell JH (1961a) Effects of competition, predation by Thais lapillus, and other factors on natural populations of the barnacle Balanus balanoides. Ecol Monogr 31:61-104
Connell JH (1961b) The influence of interspecific competition and other factors on the distribution of the barnacle, Chthamalus stellatus. Ecology 42:710-723

Creese RG (1980) An analysis of distribution and abundance of populations of the high-shore limpet, Notoacmea petterdi (Tenison-Woods). Oecologia 45:252-269

Crump RG, Emson RH (1983) The natural history, life history and ecology of the two British species of Asterina. Field Stud 5:867-882

Denley EJ, Underwood AJ (1979) Experiments on factors influencing settlement, survival, and growth of two species of barnacles in New South Wales. J Exp Mar Biol Ecol 36:269-293

Gage JD, Pearson $M$, Billett DSM, Clark AM, Jensen $M$, Paterson GLJ, Tyler PA (1984) Echinoderm zonation in the Rockall Trough (NE Atlantic). In: Keegan BF, O'Connor BDS (eds) Proceedings of 5th International Echinoderm Conference. AA Balkema, Rotterdam, p 31-36

Himmelman JH, Dutil C (1991) Distribution, population structure and feeding of subtidal seastars in the northern Gulf of St. Lawrence. Mar Ecol Prog Ser 76:61-72

Iwasaki K (1995a) Factors delimiting the boundary between vertically contiguous mussel beds of Septifier virgatus (Wiegmann) and Hormomya mutabilis (Gould). Ecol Res $10: 307-320$

Iwasaki K (1995b) Comparison of mussel bed community between two intertidal mytilids Septifier virgatus and Hormomya mutabilis. Mar Biol 123:109-119

Jangoux M (1982) Food and feeding mechanisms: Asteroidea. In: Jangoux M, Lawrence JM (eds) Echinoderm nutrition. AA Balkema, Rotterdam, p 117-159

Keough MJ, Downes BJ (1982) Recruitment of marine invertebrates: the role of active larval choices and early mortality. Oecologia 54:348-352

Kurihara T (1996) Effects of sediment and depth on species composition of starfishes (Asteroidea) in Wakasa Bay, Japan Sea. Benthos Res (Japan) 50:1-10 (in Japanese with English abstract)

Kurihara T (1998) Brand marks on the starfish, Asterina pectinifera. J Mar Biol Assoc UK 78:677-680

Kurihara $T$, Yano F (in press) Negative growth in the sea-star Asterina pectinifera (Echinodermata: Asteroidea). Asian Mar Biol

Levin VS, Ivin VV, Fadeev VI (1987) Ecology of the starfish Patiria pectinifera (Müller et Troschel) in Possiet Bay, Sea of Japan. Asian Mar Biol 4:49-60

Lubchenco J (1980) Algal zonation in the New England rocky intertidal community: an experimental analysis. Ecology 61:333-344

Maizuru Marine Observatory (1993) Tidal observation record 1993

Maizuru Marine Observatory (1994) Tidal observation record 1994

Mauzey KP, Birkeland C. Dayton PK (1968) Feeding behavior of asteroids and escape responses of their prey in the Puget Sound region. Ecology 49:603-619

Moore PA, Lepper DME (1997) Role of chemical signals in the orientation behavior of the sea star Asterias forbesi. Biol Bull 192:410-417

Nojima S (1989) Ecological studies on the sea star, Astropecten latespinosus Meissner. VI. Seasonal changes in stomach contents, preference of food items, size preference and two kinds of switching in feeding habits. Publ Amakusa Mar Biol Lab Kyushu Univ 10:17-40

Okutani $T$ (ed) (1994) Umibe no ikimono (Creatures on the seashore). Yamatokeikokusya, Tokyo (in Japanese)

Paine RT (1974) Intertidal community structure: experimental 
studies on the relationship between a dominant competitor and principal predator. Oecologia 15:93-120

Raimondi PT (1991) Settlement behavior of Chthamalus anisopoma larvae largeiy determines the adult distribution. Oecologia 85:349-360

Snelgrove PVR, Butman CA (1994) Animal-sediment relationships revisited: cause versus effect. Oceanogr Mar Biol Annu Rev 32:111-177

Stevenson JP (1992) A possible modification of the distribution of the intertidal seastar Patiriella exigua (Lamarck) (Echinodermata: Asteroidea) by Patiriella calcar (Lamarck). J Exp Mar Biol Ecol 155:41-54

Tamura Y (1992) Seasonal changes in oceanographic environments and classification of regions from a viewpoint of turbidity in Maizuru Bay. Masters thesis, Kyoto University Faculty of Agriculture (in Japanese)

Editorial responsibility: Otto Kinne (Editor).

Oldendorf/Luhe, Germany
Ueno M, Satoh K (1994) Oceanographic observation record. Rep Fish Res Stn Kyoto Univ 3:48-52

Underwood AJ (1997) Experiments in ecology. Cambridge University Press, Cambridge

Underwood AJ, Barrett G (1990) Experiments on the influence of oysters on the distribution, abundance and sizes of the gastropod Bembicium auratum in a mangrove swamp in New South Wales, Australia. J Exp Mar Biol Ecol 137 : $25-45$

Underwood AJ, Denley EJ (1984) Paradigms, explanations, and generalizations in models for the structure of intertidal communities on rocky shores. In: Strong DR Jr, Simberloff $D$, Abele LG, Thistle AB (eds) Ecological communities. Princeton University Press, Princeton, NJ, p 151-180

Zar JH (1996) Biostatistical analysis, 3rd edn. Prentice-Hall, Engelwood Cliffs, NJ

Submitted: November 24, 1997; Accepted: January 7, 1999 Proofs received from author(s): April 23, 1999 